\title{
The 'New' Adjacency Pairs in Online Learning: Categories and Practices
}

\author{
Laila Ulsi Qodriani ${ }^{1,2, *}$, I Dewa Putu Wijana ${ }^{2}$
}

\author{
${ }^{1}$ Faculty of Arts and Education, Universitas Teknokrat Indonesia, Bandarlampung 35114, Indonesia \\ ${ }^{2}$ Faculty of Cultural Sciences, Universitas Gadjah Mada, Yogyakarta 55281, Indonesia \\ *Corresponding author. Email: ani@teknokrat.ac.id
}

\begin{abstract}
Covid-19 pandemic situations have changed the view of the educational sector in our life. One of them is the fully online learning method, where this type of new-media-way communication offers its escape to solve the teaching-learning activity during this emergency condition. In this computer-mediated communication, the analysis and interpretation of turn sequences consider creating a smooth mediated communication. Thus the issue on adjacency pairs then draws our attention. The empirical data under discussion concerns the online learning activity through SPADA Learning Management System (LMS) in 12 tertiary classes in a private university in Bandar Lampung, Indonesia, by systematic virtual observation. The everyday exchanges of text messages among the virtual classroom interaction and detailed linguistic analysis contribute to understanding the adjacency pair's practices and categories. The result says that there are no prominent differences between spoken adjacency pairs and online written communication; however, some linguistics details may 'renew' it in the form of uses that can be considered for future online learning communication.
\end{abstract}

Keywords: pairs, turn, online, communication, sequence

\section{INTRODUCTION}

The practice of online learning in 2020 has started to become the trend in the pandemic Covid-19 situation. The teaching-learning activity moved into the digital classroom and computer-mediated communication. This emergency condition then forced all education levels to adapt to the new-way-of communication from face-to-face to computer-mediated.

The oral communication that usually becomes the primary teaching-learning activity method suddenly moved into written communication in online learning. Thus, this change also has an impact on the classroom conversation. If it is in oral communication, the sequences can be created from various turn-taking, then in written communication, the turning sequences has their differences.

Organizing words uttered in conversation turn-taking will contribute to the excellent notion to keep the living discussion. This focus then brings us to the adjacency pairs (AP). Paltridge [1] stated that "adjacency pairs are the utterances produces by two successive speakers in a way that the second utterances is identified as related to the first one as an expected follow-up to that utterance." In a classroom interaction, these pairs are the signal to show that the teaching-learning activity goes well. The teacher can somehow portray their student's responses from their pairs. It is in line with the function of AP itself in contributing to the flow of the conversation (Levinson [2], Richard \& Smith [3], Coulthard [4], Yule [5])
In discussing the AP's of conversation sequences, the implementation of Conversation Analysis is one of the ways to see the turn-taking pattern in whether interlocutors participate in a conversation. This shows the uniqueness of analyzing language and human social interaction [6]. AP's is a sequence of two turns which is produced adjacently and related to each other. So, the utterances produced by two different speakers. Each speaker has it each turn as the first part pair (FPP) and the second pair part (SPP). The turn can be specified as a pair typed as a requirement so that the FPP of a particular type that SPP requires has the same type (Schegloff \& Sacks [7] Sacks [8]). There are some common AP's and some typical preferred and dispreferred part of SPP:

\begin{tabular}{l|ll} 
FPP $\left(\mathbf{1}^{\text {st }}\right)$ & \multicolumn{2}{|c|}{$\mathbf{S P P}\left(\mathbf{2}^{\text {nd }}\right)$} \\
& Preferred & Dispreffered \\
Request & Acceptance & Refusal \\
Offer/Invite & Acceptance & Refusal \\
Assesment & Agreement & Disagreement \\
Question & Expected Answer & Unexpected Answer \\
Blame & Denial & Admission
\end{tabular}

\subsection{Some Related Studies}

There are various researcher have done some AP's analysis. In example Syarifuddin and Hasyim [9] has researched types of spoken language for English Language Teaching. Their focus on the practice of spoken English to the country in which its first language is not English in 
some university speaking classes in Indonesia. The finding was the AP's, turn-taking, and the exchange was the most varied and complex implemented during the course. For the AP's it is found that greeting/greeting and greeting/apology is the most dominant.

On the other side, Rum [10] analyzed the AP's of students and teachers in ELC Education in Makassar. The study revealed there are five AP's in the teaching-learning process. First, degreeting/degreeting pair which functions as an agreement to discontinue the particular conversation. Second, greeting/greeting pair also has a similar function as the previous pair, an agreement to terminate the specific discussion. Third, a question/refusal pair. It functions as questioning and refusing utterance where there is a question and follows by a refusal. Then, an offer/refusal pair during the classroom interaction where there is an offer and the other speaker accepts the related utterance. The last pair is a question/answer. It functions as questioning and answering to the related remark

Nafi' et.al. [11] tried to find out the AP's in other different types of the classroom. The study investigated the AP's component in a conversation between an English teacher and hearing-impairment students in a special needs classroom. The research resulted in 9 kinds of AP's committed from the interaction. They are compliment/acceptance, information/acknowledgment, greeting/greeting, invitation/acceptance, offer/refusal, question/answer, summons/answer, accusation/denial, offer/acceptance. The study revealed that an active interaction between teachers and students exists through various AP's occur in the special needs classroom, even though the teacher's role is also quite influential in the special needs classroom.

Later, the discussion on AP's was also found in Bone [12] which discussed the interaction between tutor-tutee in online English learning. The talk-in conversation utilized the CA framework of Sacks et.al.on turn-taking system, sequence organization, turn design, and repair organization. In sequence organization, the typical AP's revealed in the study are greeting/greeting, question/answer, request/acceptance, suggestion/acceptance, farewell/farewell. However, though the interaction lies in online communication, this study looks at the naturalness of the language used from oral synchronous communication or direct conversation in distance learning.

The sequences of face-to-face $(\mathrm{FtF})$ classroom and online learning (OL-L) conversation is different. If in $\mathrm{FtF}$ classroom, AP's turn-taking sequences can be in an interruption, which can influence the speaker role, in OL$\mathrm{L}$, the stages of turn allocation put them in an orderly arrangement, and the role of the speaker is hard to be changed. This distinction then draws our attention to dig out more about the AP's in OL-L. From the slight discovery of some previous studies, there are still rare to find the AP's analysis of written communication. And to fill this gap, this research then aims to investigate the types of AP's in OL-L and types of communicative functions that reflected from the practice of AP's in computermediated communication which performs in written communication. The research then starts by questioning on what are the types of AP's in OL-L and what communicative function are reflected in AP's in OL-L.

\section{METHOD}

To analyze the dynamic of questions and answers when teachers and students interact, there are 12 Learning Management System (LMS) from the platform of SPADA Indonesia of a private university in Bandar Lampung, Indonesia were recorded and taken from the site. The data were taken from the system by considering some ethical permission and access of the researchers. The form of communication was in an entirely written conversation.

The teacher-student communication performed in Forum Discussion features of SPADA. Therefore, to focus on the main discussion of APs the data then selected only if it consists of minimally two speakers. Next, to analyzed and interpreted the data, the Conversation Analysis approach was used. The Conversation Analysis attempts to closely examine natural talks to the different structures and rules that govern the conversation and social actions [13]. The extract of each utterance is then classified and categorized by its turn sequences and communicative function

\section{FINDING \& DISCUSSION}

In this particular situation, the teacher and the student interchanging their ideas, opinions, and concepts in a distance classroom. The activity was done in a synchronous textual computer-mediated communication. After analyzing the interchange of information determined between student and teacher, the result reveals that there are the following categories of adjacency pairs found:

\section{$\underline{\operatorname{FPP}\left(1^{\text {st }}\right) \text { VS SPP }\left(2^{\text {nd }}\right)^{*}}$}

Greeting VS Greeting

$97 \%$

Question VS Expected Answer

$83 \%$

Information VS Acknowledgement

$69 \%$

Question VS Response - Feedback $\quad 66 \%$

Request VS Acceptance

$43 \%$

* First Pair Part VS Second Pair Part

\section{Greeting/Greeting}

\section{Excerpt 1:}

T : "Hi, everyone! Welcome to Child Development subject. As you have joined this course this semester and this becomes our first meeting, please drop your "Hello!" as you are attending this course and you are ready to join this online learning." 
S1 : "Hello"
S2 : "Hello"

Etc.

Basically, there are no differences in greeting between FtF classroom and OL-L. It can be seen from the pair that happen in this greeting part where the second speaker of this conversation also replies by a greeting. Things that make them different is, in doing the greeting in a OL-L as well as the act of opening the class, the teacher can not only use the greeting expression that commonly used in spoken interaction. To trigger the next speaker in this written communication situation, especially in a classroom situation where both teacher and student needs to attach each other, this teacher then use a creative statement by asking their student to 'drop' their 'hello!' which means he/she ask their student to reply by typing their 'Hello!' as their response to the existing conversation. The result is, all the student respond to it by greeting their Hello!. The teacher uses the APs practices in this set of interaction as their strategy to give the floor to the student for their actions in taking the turn in a conversation.

\section{Question/Expected Answer}

\section{Excerpt 2:}

T : "Hi everyone!

Have you read the slides and videos of today's topic?

After you have finished reading and watching them,

now please give your opinion about this question,

"How does socioeconomic influence someone's growth and development?."

S1 : "economic factors that influence the development and growth of a person are internal and external factors consisting of internal factors namely genes, age, hormones, race and gender that are all owned by each person, while from external factors namely nutrition, disease, infection, work, human feelings, environmental sanitation, good stimulation, socioeconomic conditions that are owned by each person but are different."

Etc.

It is a common technique in a teaching-learning activity if the teacher uses the Q \& A to explain a topic to their student. The Q \& A session can help the teacher to see a better understanding of their student in a particular discussion. Therefore, as it is named as Q \& A, the pairs that should happen is when the teacher is giving a question; then it responded by the student in an expected answer. However, as we can see in extract 2, literally there lie two different questions given by the teacher to the student:

1. "have you read the slides and video of today's topic"
2. "how does the socioeconomics influence someone's growth and development and development?".

Yet, based on the data finding none of the student answering the first question. If we barely see it in the practices of AP's, the first question means it has no pairs. Question number 1 resulted in no responses from the student. But, this does not indicate the conversation is failed.

If we put the setting in a FtF classroom, we can imagine that the teacher can easily see the students' response in every question given by the teacher. This pairing action is one of the ways of students' to show their participation in a specific discussion with their teacher. Thus, this not always happen in an online written communication. Though we can see there are some similarities lies between $\mathrm{FtF}$ and $\mathrm{OL}$ interaction where the textual communication somehow was the oral-written form with the similar naturalness of the language. However, there is one type that distinguished them. As what stated by Herring [14] and Herring et.al. [15] the written communication, especially in computer-mediated communication, the character of users tend to simplify their language as well as their way of communication. The reason for this act can possibly happen because of the different ways of producing the language; oral (speak) versus written (type). Therefore, if we go back to excerpt 2, where all of the students skip their response in answering question 1, this does not mean them as ignoring the conversation. In fact, the students have just highlighted the main question given by the teacher to have a more superficial understanding of their discussion.

\section{Information/Acknowledgement}

\section{Excerpt 3:}

T : "Good day ladies \& gentlemen, I'm XXX, the lecturer for this class.

I'll be with you discussing and directing what to do during this semester in this particular 'on-line' history of modern thought class. We'll be discussing the content of our "temporary" learning contract. I'll show you some important points related to our subject and you're pleased to ask if any queries.

Remember, we only have approximately 100 minutes to discuss all things needed, and each of you are required to post something in this forum.

Thanks in advance."

S1 : "Good morning, Sir.

I am YYY, 16111076. I am 7th semester student batch

Etc. 2016. Thank you Sir"

Extract 3 is one of the examples of information/acknowledgment pairs practice. The teacher opens this conversation in the form of self-introduction and further explains about his class. The utterances that 
stated by the teacher is full-on what to do and what to have during their online class activity. In responding to this type of statement, the student then takes their turn by also giving their self-introduction. The action that they create are based on the way of the first speaker set on this conversation. In this situation, we can see that the pair show that when the teacher was giving specific information, the student will acknowledge it in the same way.

\section{Question/Response/Feedback}

\section{Excerpt 4:}

S : Good morning sir, I want to ask about Totemism. Who has given the concept of totemism?

Thank you sir.

$\mathrm{T}$ : In the context of anthropology, it was Emile Durkheim who ever conducted research on Totemism. Durkheim sees this as a communal belief system, in which they believe that God presents in the forms of animal and plant. Word totem itself is derived from Algonkin tribe in North America

\section{S : Okay sir.. I got it thank you.}

The example in excerpt 5 was the typical interaction that happen in a classroom activity. This is in line with the theory of IRF (Initiation-Response-Feedback) proposed by Richard and Schmidt [16]. The student has initiated the conversation by giving the question to the teacher; the next part is the teacher answering the student's question and, to end the set of discussion, the student giving their feedback. Though the pairs in this type of conversation consisted of more than two utterances, this was performed into one package of sequences. The question proposed by the student does not merely end in the answer of the teacher. In this kind of situation, the teaching-learning process, the teacher also needs the next feedback from the student whether his explanation on the question's answer can be understood by the student or not. And or, whether the student's already found the answer to his/her question.

\section{Request/Acceptance}

\section{Excerpt 5:}

T : Alright ladies \& gentlemen,

It's nice to know you have such a basic understanding on human culture during prehistoric period. I do really appreciate it.

\section{Now, it is my turn to explain the material!}

Please hold your response while waiting for me finishing the material. Right after I declare $Q \& A$ session, then you may give some responses.

Let me have couple of minutes to post the material.
In this except 5 we can see some requests given by the teacher to the student. In OL-L situation where the social presence of body language, eye contact, hand movement, and body gesture is enabled to support the conversation, so the form of written communication then changed into the detailed instruction. To have good communication and successful teaching-learning activity, the precise order's intention and meaning should be put in the first place. This has the function to ease each of the participants of the classroom in avoiding miscommunication or misleading on the classroom activity. For example let us see the sample of detailed order in excerpt 5 :

1. Knowing a basic understanding of the material

2. Giving the teacher their turn in explaining

3. Holding the response

4. Waiting for the teacher in finishing their presentation

By knowing the request made by the teacher, the student then can respond to their acceptance/agreement or refusal/disagreement of the statement/utterances in creating the pairs.

\section{CONCLUSION}

The everyday exchanges of text messages among the virtual classroom interaction and detailed linguistic analysis contribute to understanding the adjacency pair's practices and categories in computer-mediated communication. The result says that several types of adjacency pairs are found, such as greeting/greeting. Question/answer, information/acknowledgement, question-response-feedback, request/acceptance.

Although there are no prominent differences between spoken adjacency pairs and online written communication adjacency pairs; however, some linguistics details may 'renew' it in the form of uses that can be considered for future online learning communication.

\section{ACKNOWLEDGMENT}

This work was financially supported by the Research and Social Services Department of Universitas Gadjah Mada as granted in Rekognisi Tugas Akhir (RTA) grant. For the first author, it is also supported by the academic scholarship from Universitas Teknokrat Indonesia.

\section{REFERENCES}

[1] Brian Paltridge, Discourse Analysis: An Introduction $2^{\text {nd }}$ Ed. London, Continuum, 2012.

[2] S.C. Levinson, Pragmatics, London, Cambridge University Press, 1983

S : Ok Sir 
[3] J.C. Richards, R. Schmidt, Conversational Analysis, in J.C. Richards and Schmidt (eds), Language and Communication, London, Longman, 1983.

[4] M. Coulthard, An Introduction to Discourse Analysis, London, Longman, 1985.

[5] Yule, George, Pragmatics, Oxford, Oxford University Press, 1996.

[6] E. A. Schegloff, G. Jefferson, H. Sacks, the preference for self- correction in the organization of repair in conversation. Language, 1997, pp. 361-382.

[7] E.A. Schegloff, H. Sacks, opening up closings, Semiotica, 8(4) (1973), pp. 289- 327.

[8] H. Sacks, Lectures on conversation vol. 1 \& 2, London, Blackwell, 1992.

[9] Salmia syarifuddin, Irmawati Hasyim, a review in spoken language teaching, Jurnal Bahasa, Sastra dan Budaya Tamaddun, 18 (1) (2019).

[10] Muhammad Rum, discourse analysis: analyzing adjacency pairs of teacher and students, IDEAS: Journal on English Language Teaching and Learning, Linguistics and Literature, [S.1.], 5 (2) (2018).

[11] Nahar Nurun Nafi', Desika Rinanda, Sularti, the adjacency pairs analysis of teacher students talks in hearing impairment classroom, Register Journal, 12(1) (2019) pp. 81-99. http://dx.doi.org/10.18326/rgt.v12i1.8199

[12] Janice C. Bone, tutor-tutee online learning of the English language: a conversation analysis, Global Scientific Journal, 6 (7) (2018), pp 347-414.

[13] J. Pineda, classroom interaction: a dynamic of questions and answers, Enletawa Journal, 8 (2) (2015), pp. $15-33$.

[14] Susan Herring, computer-mediated discourse, in D. Schiff rin, D. Tannen, H. Hamilton (Eds.), The Handbook of Discourse Analysis, Oxford, Blackwell, 2001, pp. 612634.

[15] Susan Herring, L. Scheidt, E. Wright, S. Bonus, weblogs as a bridging genre, Information Technology \& People, 18 (2) (2005), pp.142-171.

[16] J.C. Richards, and R. Schmidt, conversational analysis, in J.C. Richards and Schmidt (eds), Language and Communication, London, Longman, 1983. 